\title{
Penicillin-Binding Proteins and Carboxypeptidase/Transpeptidase Activities in Proteus vulgaris P18 and Its Penicillin-Induced Stable L-Forms
}

\author{
ANDRÉ ROUSSET, ${ }^{1}$ MARTINE NGUYEN-DISTÈCHE, ${ }^{2}$ RAYMOND MINCK,${ }^{1}$ AND JEAN-MARIE \\ GHUYSEN $^{2 *}$
}

Université de Strasbourg, Faculté de Médecine, Institut de Bactériologie, F-67000 Strasbourg, France ${ }^{1}$; and Service de Microbiologie appliquée aux sciences pharmaceutiques, Faculté de Médecine, Institut de Chimie, Université de Liège, B-4000 Sart Tilman (Liège), Belgium ${ }^{2}$

Received 25 June 1982/Accepted 3 September 1982

\begin{abstract}
The originally penicillin-induced, wall-less stable L-forms of Proteus vulgaris P18, isolated by Tulasne in 1949 and since then cultured in the absence of penicillin, have kept the ability to synthesize the seven penicillin-binding proteins and the various DD- and LD-peptidase activities found in the parental bacteria and known to be involved in wall peptidoglycan metabolism. The stable L-forms, however, secrete during growth both the highly penicillin-sensitive, DD-carboxypeptidase-transpeptidase penicillin-binding protein PBP4 (which in normal bacteria is relatively loosely bound to the plasma membrane) and the penicillininsensitive LD-carboxypeptidase (which in normal bacteria is located in the periplasmic region).
\end{abstract}

The rod-shaped enterobacteria can give rise by a penicillin-induced process to two types of coccal L-forms. The unstable L-forms (spheroplasts) have defects in their wall peptidoglycan and are osmotically fragile. The induced lesion is reversible, and upon removal of penicillin from the growth medium, both normal peptidoglycan synthesis and reversion to the original bacteria occur. In contrast, the stable L-forms (protoplasts) grow as permanently wall-less, ovoid organisms and can do so under conditions of normal osmotic stabilization whether penicillin is present or not $(1,8,25)$. Like the other enterobacteria studied $(4,5,20)$, Proteus mirabilis possesses seven penicillin-binding proteins (PBPs), referred to as PBP1A, 1B, 2, 3, 4, 5, and 6 (in the order of decreasing molecular weight). On the basis of the PBP pattern of the normal bacteria and that of the corresponding stable Lforms, Martin et al. (13) have suggested that the permanent inability of these L-forms to synthesize a normal peptidoglycan might be related to the hereditary and selective loss of PBP4. PBP4 is known to be a D-alanyl-D-alanine-cleaving peptidase which is able to show, on well-defined substrates, carboxypeptidase, transpeptidase, and endopeptidase activities (22). In view of the importance of the wall-less growth forms of bacteria in clinical cases, another stable L-form originating from Proteus vulgaris $\mathrm{P} 18$ has been investigated and compared with its parental strain. This stable L-form was isolated by $\mathrm{Tu}-$ lasne in 1949 as a penicillin-resistant organism
(25). Since then, the cells have been subcultured twice weekly in suitable growth medium in the absence of penicillin.

(This paper is from a dissertation submitted by A.R. in partial fulfillment of the requirements for a degree of Docteur ès Sciences at the University of Strasbourg, Strasbourg, France.)

\section{MATERIALS AND METHODS}

Strains and growth conditions. $P$. vulgaris $\mathrm{P} 18$ was grown at $37^{\circ} \mathrm{C}$ with shaking in standard Merck I broth medium, and the cells were harvested at the midlog phase (optical density at $600 \mathrm{~nm}, 1$ ). The stable Lforms were grown at $37^{\circ} \mathrm{C}$ either without shaking in the modified Medill-O'Kane medium (17) or with shaking in the modified Medill-Brown medium (16). Both cultures gave identical results.

Preparation of the cell envelopes. Three procedures were used to prepare the cell envelopes from the normal bacteria.

(i) Standard procedure (via spheroplasts formation). Cells $(1 \mathrm{~g}$, wet weight) were suspended in $30 \mathrm{ml}$ of 50 $\mathrm{mM}$ Tris-hydrochloride buffer ( $\mathrm{pH}$ 8.0) containing 0.75 $M$ sucrose and $40 \mathrm{mg}$ of lysozyme, and the suspensions were submitted to successive freezing and thawing. After an osmotic shock in distilled water, the cell envelopes were collected by centrifugation. For more details, see references 9 and 11 .

(ii) Ribi procedure. Cells (1g, wet weight) were suspended in $5 \mathrm{ml}$ of $10 \mathrm{mM}$ Tris-maleate buffer $(\mathrm{pH}$ 7.0) containing $1 \mathrm{mM} \mathrm{MgCl}$, and the suspension was treated with a Ribi press at $30,000 \mathrm{lb} / \mathrm{in}^{2}$ and a temperature ranging between 4 and $15^{\circ} \mathrm{C}(21)$. The cell envelopes were collected by centrifugation.

(iii) Modified Nossal-Heppel procedure (19). Cells (collected from 1 liter of culture) were successively (i) 
plasmolyzed for $15 \mathrm{~min}$ at $25^{\circ} \mathrm{C}$ in $100 \mathrm{ml}$ of $10 \mathrm{mM}$ Tris-hydrochloride buffer (pH 7.3) containing $30 \mathrm{mM}$ $\mathrm{NaCl}, 0.5 \mathrm{mM}$ EDTA, and $0.58 \mathrm{M}$ sucrose (centrifugation gave rise to a supernatant $\mathrm{S} 1$ ); (ii) rapidly homogenized in $100 \mathrm{ml}$ of distilled water at $4^{\circ} \mathrm{C}$ (centrifugation gave rise to a supernatant S2); (iii) treated for 30 min at $4^{\circ} \mathrm{C}$ with $5 \mathrm{ml}$ of $10 \mathrm{mM}$ Tris-hydrochloride buffer ( $\mathrm{pH}$ 7.3) containing $1 \mathrm{M} \mathrm{NaCl}$ (centrifugation gave rise to a supernatant S3); and (iv) submitted to sonication with a Measuring Scientific Equipment apparatus at 25,000 $\mathrm{Hz}$ and at $0^{\circ} \mathrm{C}$ (centrifugation gave rise to a supernatant $S 4$ and a pellet which consisted of cell envelopes). Each supernatant was dialyzed against $0.25 \mathrm{M}$ Trishydrochloride buffer ( $\mathrm{pH} \mathrm{8.9)}$ and concentrated by ultrafiltration to $4 \mathrm{ml}$.

The cell envelopes of the stable $L$-forms were prepared according to the standard procedure described above, but without supplemental lysozyme. In all cases, the cell envelopes were suspended in $0.25 \mathrm{M}$ Tris-hydrochloride buffer ( $\mathrm{pH} \mathrm{8.9)}$ at a concentration of about $50 \mathrm{mg}$ of protein per $\mathrm{ml}$. They were stored in the frozen state at $-20^{\circ} \mathrm{C}$.

Protein determination. The proteins were estimated by the technique of Lowry et al. (10) with bovine serum albumin as a standard and in the case of the cell envelope, in the presence of sodium dodecyl sulfate as described previously (23).

PBP analysis. Samples $(45 \mu \mathrm{l})$ of the cell envelopes (150 $\mu \mathrm{g}$ of protein) or the solubilized enzyme preparations (at a proper concentration) were incubated with $\left[{ }^{14} \mathrm{C}\right]$ benzylpenicillin (from the Radiochemical Centre, Amersham; final specific radioactivity, $50 \mathrm{mCi} / \mathrm{mmol}$ ) at the indicated concentration for $10 \mathrm{~min}$ at $37^{\circ} \mathrm{C}$, and the reaction was terminated by the addition of $8 \mathrm{mM}$ (final concentration) nonradioactive benzylpenicillin and $1 \%$ (wt/vol, final concentration) Sarkosyl. After centrifugation (in the case of the cell envelopes), the

tween the PBPs and $\left[{ }^{14} \mathrm{C}\right]$ benzylpenicillin were estimated by the technique of Spratt (24). The thermolability of the native PBPs (before reaction with radioactive benzylpenicillin) was determined as described by Ohya et al. (20). The apparent molecular weights of the PBPs were determined by comparing their mobilities on the gels with those of myoglobin $\left(M_{\mathrm{r}}, 17,800\right)$, chymotrypsinogen A $\left(M_{\mathrm{r}}, 25,000\right)$, ovalbumin $\left(M_{\mathrm{r}}, 43,000\right)$, and bovine serum albumin $\left(M_{\mathrm{r}}\right.$, 68,000 ).

Analytical polyacrylamide gel electrophoresis at $\mathbf{p H}$ 8.3 under nondenaturing conditions. Electrophoresis was carried out on cylindrical gels $(0.9$ by $12 \mathrm{~cm}$; containing $7 \%$ acrylamide and $0.2 \% N N^{\prime}$-methylene bisacrylamide) in $25 \mathrm{mM}$ Tris-glycine buffer ( $\mathrm{pH} \mathrm{8.3)}$. After preelectrophoresis of the gels for $1 \mathrm{~h}$ at $1 \mathrm{~mA} / \mathrm{gel}$, the enzyme samples were submitted to electrophoresis for about $3 \mathrm{~h}$ at $4^{\circ} \mathrm{C}$ and $2 \mathrm{~mA} / \mathrm{gel}$. Bromophenol blue was used as a marker. After electrophoresis, the gels were sliced into 2-mm-thick disks, the disks were eluted with $300 \mu$ l of $0.1 \mathrm{M}$ Tris-hydrochloride buffer (pH 8.9), and the eluates were assayed for enzyme activity.

DD-Carboxypeptidase, DD-transpeptidase, and LD-carboxypeptidase assays. All reactions were carried out at $37^{\circ} \mathrm{C}$ in $30 \mu \mathrm{l}$ (final volume) of $0.25 \mathrm{M}$ Tris-hydrochloride ( $\mathrm{pH}$ 8.9) containing $2 \times 10^{-4} \mathrm{M}$ dithiotreitol. For details, see reference 18. D-Alanyl-D-alanine-cleaving carboxypeptidase (in short, DD-carboxypeptidase) activity was estimated by measuring the amount of D$\left[{ }^{14} \mathrm{C}\right] \mathrm{Ala}$ released from the nucleotide-pentapeptide UDP- $N$-acetylmuramyl-L-Ala- $\gamma$-D-Glu-(L)-meso$A_{2}$ pm-(L)-D- $\left[{ }^{14} \mathrm{C}\right]$ Ala-D- $\left[{ }^{14} \mathrm{C}\right]$ Ala $(1.33 \mathrm{mM}$; specific radioactivity, $22 \mathrm{mCi} / \mathrm{mmol}$ ). D-Alanyl-D-alaninecleaving transpeptidase (in short, DD-transpeptidase) activity was estimated by measuring the amount of radioactive monoamidated peptide dimer

$$
\begin{aligned}
& \text { L-Ala- } \gamma \text {-D-Glu(amide)- } \frac{\mathrm{L}}{\mathrm{A}_{2}^{\prime} \mathrm{pm}}-(\mathrm{D}-\mathrm{Ala}) \\
& \text { L-Ala- } \gamma-D-G l u-(L)-m e s o-A_{2} \text { pm-(L)-D- }\left[{ }^{14} \mathrm{C}\right] \text { Ala- } \frac{}{\frac{1}{D}}
\end{aligned}
$$

samples were boiled in the presence of $1 \%$ sodium dodecyl sulfate and $11.6 \%$ mercaptoethanol, and the PBPs were separated by polyacrylamide $(10 \%)$ slab gel electrophoresis at $\mathrm{pH} 8.3$ in the presence of sodium dodecyl sulfate and visualized by fluorography. The time of exposure at $-70^{\circ} \mathrm{C}$ to prefogged $\mathrm{X}$-ray film was 8 weeks. For more details, see reference 24 . Relative band intensities on the fluorograms were estimated with a microdensitometer (Beckman DU-8; Beckman Instruments, Inc., Fullerton, Calif.) with peak integration. Saturation of the PBPs was carried out by using increasing concentrations of $\left[{ }^{14} \mathrm{C}\right]$ benzylpenicillin (up to $\left.5 \times 10^{-4} \mathrm{M}\right)$. The affinities of various nonradioactive $\beta$-lactam compounds for the PBPs were determined by competition with $\left[{ }^{14} \mathrm{C}\right]$ benzylpenicillin and expressed as the concentrations necessary to inhibit by $50 \%$ further binding of $\left[{ }^{14} \mathrm{C}\right]$ benzylpenicillin. For this purpose, the cell envelopes were exposed to serial dilutions of the various antibiotics for $10 \mathrm{~min}$ at $37^{\circ} \mathrm{C}$, and then $\left[{ }^{14} \mathrm{C}\right]$ benzylpenicillin $(0.2 \mathrm{mM}$, final concentration) was added. After a further $10 \mathrm{~min}$ of incubation, the reaction was terminated as above by the addition of nonradioactive benzylpenicillin and Sarkosyl. The half-lives of the adducts formed be- formed from a mixture of radioactive pentapeptide $\mathrm{L}-$ Ala- $\gamma$-D-Glu-(L)-meso-A pm-(L)-D- $\left[{ }^{14} \mathrm{C}\right]$ Ala-D- $\left[{ }^{14} \mathrm{C}\right]$ Ala (1.33 $\mathrm{mM}$; specific radioactivity, $22 \mathrm{mCi} / \mathrm{mmol})$ and amidated tetrapeptide L-Ala- $\gamma$-D-Glu(amide)-(L)meso-A $\mathrm{A}_{2} \mathrm{pm}-(\mathrm{L})-\mathrm{D}-\mathrm{Ala}(13.3 \mathrm{mM})$. meso-Diaminopimelyl-(L)-D-alanine-cleaving carboxypeptidase (in short, LD-carboxypeptidase) activity was estimated by measuring the amount of D-Ala released from the nucleotide-tetrapeptide UDP- $N$-acetylmuramyl-L-Ala- $\gamma$ D-Glu-(L)-meso-A pm-(L)-D-Ala (1.33 mM). Free DAla was estimated as described previously (2). One unit of these enzymes hydrolyzed or catalyzed the synthesis of $1 \mu \mathrm{eq}$ of appropriate linkages per min.

D $_{\text {so }}$ values. The DD-peptidases (but not the LDcarboxypeptidase) were sensitive to $\beta$-lactam antibiot-

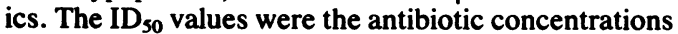
which inhibited the enzyme activities by $50 \%$.

Isolation of the highly penicillin-sensitive DD-peptidase PBP4, the moderately penicillin-sensitive DD-peptidase PBP5, and the penicillin-insensitive LD-carboxypeptidase. Normal bacteria (90 g, wet weight) suspended in $450 \mathrm{ml}$ of $10 \mathrm{mM}$ Tris-maleate buffer (pH 7) were disrupted with a Ribi press (see above), and the resulting preparation was submitted to centrifuga- 
tion for $6 \mathrm{~h}$ at $200,000 \times \mathrm{g}$. The supernatant fraction and the membrane pellet were treated as follows (all the operations were carried out at $4^{\circ} \mathrm{C}$ ).

The supernatant $(465 \mathrm{ml})$ was submitted to $\left(\mathrm{NH}_{4}\right)_{2} \mathrm{SO}_{4}$ fractionation. The precipitate collected at 30 to $60 \%$ saturation, which contained $75 \%$ of the highly penicillin-sensitive DD-peptidase and $95 \%$ of the insensitive LD-peptidase, was dissolved in $60 \mathrm{ml}$ of $0.25 \mathrm{M}$ Tris-hydrochloride buffer (pH 8.9) supplemented with $0.2 \mathrm{mM}$ dithiothreitol. After dialysis against the same buffer, the enzyme solution was filtered through a column $(2.6$ by $31 \mathrm{~cm})$ of DEAE-Sephadex. The column was washed and then treated with two successive $\mathrm{NaCl}$ gradients (made in the same buffer), first from 0 to $0.15 \mathrm{M} \mathrm{NaCl}$, under which conditions the DD-peptidase was eluted (at about $0.07 \mathrm{M} \mathrm{NaCl}$ ), and then from 0.15 to $0.4 \mathrm{M} \mathrm{NaCl}$, under which conditions the LD-carboxypeptidase was eluted (at about $0.25 \mathrm{M}$ $\mathrm{NaCl}$ ). The relevant fractions (containing the separated peptidases) were pooled, and the solutions were dialyzed against the Tris-hydrochloride (plus dithiotreitol) buffer ( $\mathrm{pH} \mathrm{8.9)}$ and concentrated by ultrafiltration.

The above procedure permitted a 180 -fold enrichment of the highly penicillin-sensitive DD-peptidase (from 5 to $970 \mathrm{mU} / \mathrm{mg}$ protein; carboxypeptidase assay) with a total yield of $24 \%$ and a 300 -fold enrichment of the LD-carboxypeptidase (from 2.4 to 760 $\mathrm{mU} / \mathrm{mg}$ of protein) with a total yield of $46 \%$. The DDpeptidase could be detected and identified as PBP4 after the DEAE-Sephadex treatment. Further purification of the DD-peptidase to a final specific activity of 4 $\mathrm{U} / \mathrm{mg}$ of protein (carboxypeptidase assay) could be achieved by filtration on a column of Ultrogel AcA4-4 in $0.25 \mathrm{M}$ Tris-hydrochloride buffer ( $\mathrm{pH} \mathrm{8.9)}$ containing $0.2 \mathrm{mM}$ dithiotreitol, followed by polyacrylamide gel electrophoresis at $\mathrm{pH} 8.3$ under nondenaturing conditions. Due to the instability of the purified enzyme, the final yield was poor $(1 \%)$, but a constant ratio between DD-carboxypeptidase activity, DDtranspeptidase activity, and $\left[{ }^{14} \mathrm{C}\right]$ benzylpenicillinbinding capacity was found throughout the protein peak eluted from the Ultrogel column. Similarily, gel electrophoresis showed that these three activities were attributable to a same protein which, under the conditions used, migrated $3 \mathrm{~cm}$ toward the anode.

The membrane pellet originating from the normal bacteria was treated (at $25^{\circ} \mathrm{C}$ for $30 \mathrm{~min}$ ) with $10 \mathrm{mM}$ Tris-maleate buffer (pH 7.0) containing $1 \mathrm{mM} \mathbf{M g C l}_{2}$ and $0.5 \%$ Genapol X-100 (a gift from Farbwerke, Hoechst, Belgium). Under these conditions, the moderately penicillin-sensitive DD-peptidase was solubilized. The extract was dialyzed against $0.25 \mathrm{M}$ Trishydrochloride buffer (pH 8.9) containing $0.2 \mathrm{mM}$ dithiotreitol and $0.5 \%$ Genapol $\mathrm{X}-100$ and filtered through an ampicillin-linked Sepharose column (equilibrated against the same buffer). The column was then treated with the same buffer as above, but containing 1 $\mathrm{M} \mathrm{NaCl}$, under which conditions the DD-peptidase was eluted (12). Each step of the purification gave rise to a parallel enrichment in both DD-peptidase activity and PBP5. The final enzyme preparation had a specific carboxypeptidase activity of $60 \mathrm{mU} / \mathrm{mg}$ of protein. No PBP other than PBP5 could be detected.

The same procedures as those described above were applied to the isolation of the corresponding peptidases from growing stable L-forms. The DD-peptidase
PBP5 was isolated from the plasma membrane, but the DD-peptidase PBP4 (final specific activity, $90 \mathrm{mU} / \mathrm{mg}$ of protein in the carboxypeptidase assay) and the LDcarboxypeptidase (final specific activity, $43 \mathrm{mU} / \mathrm{mg}$ of protein) were isolated from culture fluids.

\section{RESULTS}

$P$. vulgaris $\mathrm{P} 18$ had the rod-shaped morphology and the multilayered cell envelope structure typical of the enterobacteria. In contrast, the stable L-forms were ovoid organisms of various sizes (from 0.2 to $10 \mu \mathrm{m}$ in diameter). As shown by electron microscopy after metal shadowing, they exhibited a smooth surface and possessed multiple flagella. Examination of thin sections revealed that the cell envelope consisted of only two layers of irregular thickness (plasma membrane). Both the peptidoglycan layer and the outer membrane were absent. It has been shown (14) that unstable L-forms (i.e., osmotically fragile spheroplasts) can be obtained from $P$. mirabilis with either benzylpenicillin or cefoxitin alone, but that the addition of cefoxitin to growing benzylpenicillin-induced, unstable $\mathrm{L}$-forms caused an immediate inhibition of cellular growth, showing a clear cooperative effect of these two $\beta$-lactam compounds. Such effects were not seen with the stable (protoplast-like) L-form of $P$. vulgaris P18. Benzylpenicillin, cephalothin, or cefoxitin alone as well as the combinations benzylpenicillin-cephalothin and benzylpenicillin-cefoxitin $(800$ and $80 \mu \mathrm{g} / \mathrm{ml}$, respectively, in each case) did not inhibit cellular growth.

PBP patterns of $P$. vulgaris $P 18$ and its stable $L$ form. The cell envelopes isolated from the normal bacteria via spheroplast formation (standard procedure) possessed seven PBPs (Fig. 1, track 1). After reaction with a saturating concentration of $\left[{ }^{14} \mathrm{C}\right]$ benzylpenicillin $(0.2 \mathrm{mM})$, PBP1A $\left(M_{\mathrm{r}}, 84,000\right)$, PBP1B $\left(M_{\mathrm{r}}, 77,000\right)$, PBP2 $\left(M_{\mathrm{r}}\right.$, $68,000)$, PBP3 $\left(M_{\mathrm{r}}, 63,000\right)$, PBP4 $\left(\mathrm{M}_{\mathrm{r}}, 46,000\right)$ and PBP5/6 $\left(M_{\mathrm{r}}, 43,000\right)$ occurred with a relative abundance of $14,15,4,3,5$, and $59 \%$, respectively (Table 1). Half-saturation occurred at $\simeq 0.2 \mu \mathrm{M}$ benzylpenicillin for PBP4, $\simeq 2 \mu \mathrm{M}$ for PBP1A, 10 to $15 \mu \mathrm{M}$ for PBP2, 3, and 5/6, and finally $80 \mu M$ for PBP1B (Table 2). Cephalothin action was preferentially directed against PBP1A, and PBP2 was a very specific target for mecillinam. PBP1B was the only protein whose ability to bind $\left[{ }^{14} \mathrm{C}\right]$ benzylpenicillin was not affected by heating the cell envelopes for $10 \mathrm{~min}$ at $55^{\circ} \mathrm{C}$. The adducts formed between the PBPs and $\left[{ }^{14} \mathrm{C}\right]$ benzylpenicillin showed varied stabilities with half-lives ranging from $10 \mathrm{~min}$ (PBP5/6) to $300 \mathrm{~min}$ (PBP1A) (Table 3). All these data showed that $P$. vulgaris $\mathrm{P} 18$ had a PBP pattern typical of the enterobacteria (4) and that its PBPs had the properties that one expected for a 


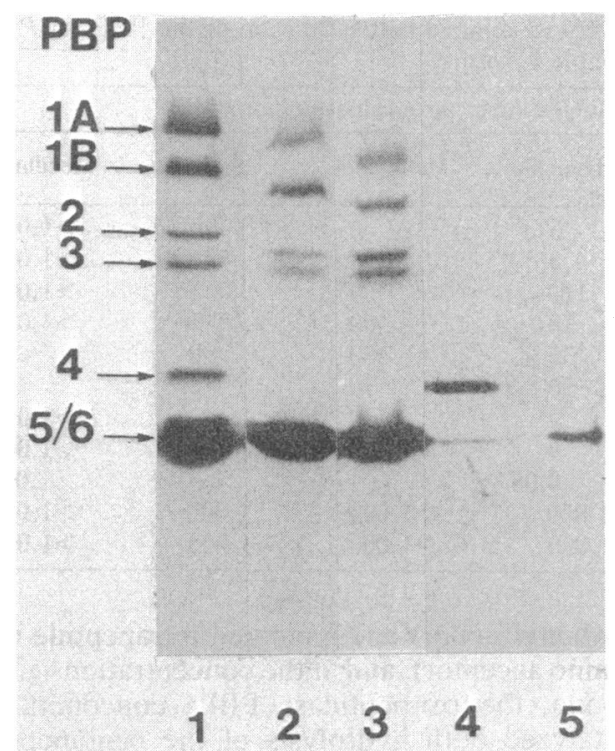

FIG. 1. PBP patterns of $P$. vulgaris P18 (tracks 1 and 2) and its stable L-forms (track 3). Analyses of the purified PBP4 (track 4) and PBP5 (track 5) isolated from normal cells. The cell envelopes of the normal bacteria were prepared via spheroplast formation (track 1) or by using the Ribi press (track 2). The isolated PBP4 was water soluble. The isolated PBP5 was in Genapol. For experimental conditions, see the text.

member of this taxonomic group (20). PBP4 was especially loosely bound to the isolated cell envelopes from which it was selectively released by treatment with $1 \mathrm{M} \mathrm{NaCl}$. Moreover, PBP4free cell envelopes were obtained by submitting the bacteria to the modified Nossal-Heppel procedure, in which case PBP4 was recovered in both fractions $\mathrm{S} 3$ and S4, or by disrupting the bacteria with the Ribi press (Fig. 1, track 2), in which case PBP4 was recovered in the supernatant fraction.

The stable L-forms were disrupted under those conditions which had permitted isolation from the normal bacteria of cell envelopes with a full assortment of PBPs. Analysis of the stable L-form cell envelopes (Fig. 1, track 3; Tables 1, 2 , and 3) showed that PBP1A, 1B, 2, 3, and 5/6 were present and had the same properties (relative abundance, affinity for $\beta$-lactam antibiotics, thermostability, and stability of the adducts formed with $\left[{ }^{14} \mathrm{C}\right]$ benzylpenicillin) as those of the normal bacteria. In some experiments (Fig. 1) the PBP1A and 1B of the stable L-forms had, somehow, reduced apparent molecular weights, but this was not always the case. PBP4, however, was always absent. Further analysis showed that the stable L-forms had not lost their ability to synthesize PBP4, but had lost their ability to anchor it in their cell envelope. During growth,
PBP4 was therefore secreted in the culture medium from which it could be isolated.

DD- and LD-peptidase activities of $P$. vulgaris P18 and its stable L-forms. The DD- and LDpeptidase activities of $P$. vulgaris $\mathrm{P} 18$ and its stable L-forms are summarized in Table 4. Cell envelopes possessing a full assortment of PBPs (i.e., prepared from normal bacterial via spheroplast formation) catalyzed both DD-carboxypeptidase and DD-transpeptidase activities. The specific activities given in Table 4 were determined on reaction mixtures containing Triton $\mathrm{X}-100$ at a $1 \%$ (vol/vol) final concentration, a condition that increased enzyme activity 10 -fold. The effects of increasing concentrations of benzylpenicillin showed that a major part $(\simeq 80 \%)$ of the total DD-carboxypeptidase activity was highly sensitive to the antibiotic $\left( \pm \mathrm{ID}_{50} \simeq 0.02\right.$ to 0.06 $\mu \mathrm{M})$, and that a minor part $(\simeq 20 \%)$ was attributable to an enzyme of moderate penicillin sensitivity $\left( \pm \mathrm{ID}_{50} \simeq 2\right.$ to $\left.6 \mu \mathrm{M}\right)$.

Cell envelopes lacking PBP4 (i.e., prepared from normal bacteria after disruption with the Ribi press or from the stable L-forms) were not competent in catalyzing transpeptidation reactions and had only a low level of DD-carboxypeptidase activity of moderate benzylpenicillin sensitivity. This DD-peptidase activity was not enhanced by the presence of Triton X-100. It was isolated (in the presence of Genapol X-100) and identified as PBP5 as described above (Fig. 1, track 5).

Both the supernatant fraction obtained after disruption of the normal bacteria with the Ribi press and the culture filtrate of the growing Lforms contained the highly penicillin-sensitive DD-carboxypeptidase-transpeptidase. This DDpeptidase was isolated and identified as PBP4 as described above (Fig. 1, track 4). An antiserum prepared against the DD-peptidase PBP4 isolated

TABLE 1. Relative abundance of the PBPs present in the cell envelopes of $P$. vulgaris P18 and its stable $\mathrm{L}$-forms as revealed by reaction with a saturating concentration $(0.2 \mathrm{mM})$ of $\left[{ }^{14} \mathrm{C}\right]$ benzylpenicillin

\begin{tabular}{cccc}
\hline & \multicolumn{3}{c}{ Relative abundance (\%) of PBPs from: } \\
\cline { 2 - 4 } PBP & \multicolumn{2}{c}{ Normal bacteria $^{a}$} & \\
\cline { 2 - 3 } & $\begin{array}{c}\text { Spheroplast } \\
\text { prepn }\end{array}$ & $\begin{array}{c}\text { Ribi press } \\
\text { prepn }\end{array}$ & L-forms \\
\hline 1A & 14 & 11 & 12 \\
1B & 15 & 13 & 12 \\
2 & 4 & 4 & 12 \\
3 & 3 & 5 & 8 \\
4 & 5 & 0 & 0 \\
$5 / 6$ & 59 & 67 & 56 \\
\hline
\end{tabular}

a The cell envelopes of the normal bacteria were prepared via spheroplast formation or by disruption with a Ribi press. 
TABLE 2. Concentration of $\beta$-lactam antibiotics necessary to achieve half-saturation of the PBPs of $P$. vulgaris P18 and its stable L-forms

\begin{tabular}{clcccccc}
\hline & & \multicolumn{5}{c}{ Concn $(\mu \mathrm{M})$ of antibiotic to achieve half-saturation of PBP } \\
\cline { 3 - 7 } & Organisms & $\begin{array}{c}\text { Benzyl- } \\
\text { penicillin }\end{array}$ & Ampicillin & Carbenicillin & Methicillin & Cephalothin & Mecillinam \\
\hline 1A & Normal bacteria & 1.8 & 1 & 5 & 6 & 0.04 & $>1,000$ \\
& L-forms & 0.5 & 1 & 3 & 18 & 0.01 & $>1,000$ \\
$1 B$ & Normal bacteria & 80 & 70 & 100 & 90 & 1 & $>1,000$ \\
& L-forms & 35 & 40 & 30 & 500 & 1 & $>1,000$ \\
2 & Normal bacteria & 9 & 4 & 30 & 400 & 90 & $<10$ \\
& L-forms & 4 & 3 & 20 & 70 & 40 & $<10$ \\
3 & Normal bacteria & 15 & 3 & 9 & 20 & 10 & $>1,000$ \\
& L-forms & 3 & 3 & 9 & 10 & 2 & $>1,000$ \\
4 & Normal bacteria & 0.2 & 0.02 & 0.08 & 1 & 3 & 1,000 \\
$5 / 6$ & Normal bacteria & 10 & 250 & 1,000 & $>1,000$ & 1,000 & $>1,000$ \\
& L-forms & 6 & $>1,000$ & $>1,000$ & $>1,000$ & $>1,000$ & $>1,000$ \\
\hline
\end{tabular}

from $P$. vulgaris P18 (specific carboxypeptidase activity, $4 \mathrm{U} / \mathrm{mg}$ of protein) maximally inhibited the activities of the enzyme by $80 \%$. It had exactly the same effect on the corresponding DD-peptidase-PBP4 of the stable L-forms.

$P$. vulgaris $\mathrm{P} 18$ and its stable $\mathrm{L}$-forms also synthesized a penicillin-resistant (and therefore not detectable as a PBP) meso-diaminopimelyl(L)-D-alanine-cleaving peptidase (equivalent to the carboxypeptidase 2 of Escherichia coli [7]). This LD-peptidase was found to be periplasmic in the normal bacteria and was selectively recovered in fractions S1 and S2 when the NossalHeppel technique was employed. The same LDpeptidase was secreted in the culture medium by the stable L-forms during growth (Table 4). The LD-peptidase was partially purified as described above.

Properties of the isolated DD- and LD-peptidases of $P$. vulgaris P18 and its stable L-forms. (i) Highly penicillin-sensitive DD-carboxypeptidasetranspeptidase PBP4. The water-soluble DD-peptidase PBP4 had an apparent molecular weight of about 46,000 (on the basis of its migration by sodium dodecyl sulfate-polyacrylamide gel electrophoresis) or 49,000 (on the basis of its $K_{d}$ value by Ultrogel filtration). It was anionic at $\mathrm{pH}$ 8.3.

With the cosubstrates, free pentapeptide (the

TABLE 3. Stability of the complexes formed between $\left[{ }^{14} \mathrm{C}\right]$ benzylpenicillin and the PBPs of $P$. vulgaris P18 and its stable L-forms

\begin{tabular}{ccc}
\hline \multirow{2}{*}{ PBP } & \multicolumn{2}{c}{ Half-life (min) of the complexes } \\
\cline { 2 - 3 } & Normal bacteria & L-forms \\
\hline 1A & 300 & 320 \\
1B & 240 & 220 \\
2 & 120 & 110 \\
3 & 180 & 155 \\
4 & 180 & Absent \\
$5 / 6$ & 10 & 12 \\
\hline
\end{tabular}

carbonyl donor) and amidated tetrapeptide (the amino acceptor), and at the concentrations given above, the DD-peptidase PBP4 concomitantly catalyzed both hydrolysis of the pentapeptide (Hy) and transpeptidation (T), with a $\mathrm{Hy} / \mathrm{T}$ ratio of about 10 (under conditions where less than $25 \%$ of the radioactive pentapeptide was utilized). Optimal $\mathrm{pH}$ for enzyme activity was $\mathbf{8 . 8}$ in $0.25 \mathrm{M}$ (or less) Tris-hydrochloride buffer. The addition of $0.2 \mathrm{M} \mathrm{NaCl}$ to the same buffer inhibited the enzyme activity by $70 \%$. UDP- $N$ acetylmuramyl-pentapeptide was not used as carbonyl donor for the transpeptidation reaction although it was a substrate $\left(K_{m}=0.6 \mathrm{mM}\right)$ for the carboxypeptidase activity.

The DD-peptidase PBP4 exhibited wide variations in its sensitivity to $\beta$-lactam antibiotics (Table 5). The $\mathrm{ID}_{50}$ values thus obtained related well with the corresponding values of Table 2, except for benzylpenicillin and mecillinam. Somehow, these two antibiotics had much higher affinities for the water-soluble PBP4 than for the membrane-bound PBP4. On the basis of the rates of enzyme recovery (3), the adducts formed between the DD-peptidase and benzylpenicillin and ampicillin had half-lives of 240 and $170 \mathrm{~min}$, respectively. The inhibition of the DDpeptidase by carbenicillin was of the competitive type. The $K_{m}$ value for the substrate (UDP- $N$ acetylmuramyl-pentapeptide) varied depending on the carbenicillin concentrations used (Fig. 2). This observation was at variance with that made previously with the corresponding DD-carboxypeptidase-transpeptidase PBP4 of $\boldsymbol{P}$. mirabilis, in which case the inhibition appeared to be clearly noncompetitive (11).

(ii) Moderately penicillin-sensitive DD-carboxypeptidase PBP5. DD-Carboxypeptidase PBP5 did not catalyze transpeptidation reaction with the above system of cosubstrates. It functioned solely as a carboxypeptidase on either UDP- $N$ acetylmuramyl-pentapeptide or the free pentapeptide. It was half inhibited by a $1 \mu \mathrm{M}$ benzyl- 
TABLE 4. Specific activities of DD- and LD-peptidases of $P$. vulgaris and its stable L-forms

\begin{tabular}{|c|c|c|c|c|}
\hline \multirow[b]{2}{*}{ Organisms } & \multirow[b]{2}{*}{ Prepn } & \multicolumn{3}{|c|}{ Sp act (mU/mg) of peptidase ${ }^{a}$} \\
\hline & & $\begin{array}{l}\text { DD-Carboxy- } \\
\text { peptidase }\end{array}$ & $\begin{array}{l}\text { DD-Trans- } \\
\text { peptidase }\end{array}$ & $\begin{array}{l}\text { LD-Carboxy- } \\
\text { peptidase }\end{array}$ \\
\hline \multirow[t]{3}{*}{ Normal bacteria } & $\begin{array}{l}\text { Cell envelopes prepared via } \\
\text { spheroplast formation }\end{array}$ & $10(\mathrm{H} \text { and } \mathrm{M})^{c}$ & $1(\mathrm{H})$ & $\mathrm{ND}^{d}$ \\
\hline & $\begin{array}{l}\text { Cell envelopes disrupted in Ribi } \\
\text { press }\end{array}$ & $0.5(\mathrm{M})$ & ND & ND \\
\hline & $\begin{array}{l}\text { Supernatant after disruption } \\
\text { with Ribi press }\end{array}$ & $5(\mathrm{H})$ & $0.5(\mathrm{H})$ & $2.4(\mathrm{R})$ \\
\hline L-forms & $\begin{array}{l}\text { Cell envelopes } \\
\text { Culture filtrate }\end{array}$ & $\begin{array}{l}0.7(\mathrm{M}) \\
5.7(\mathrm{H})\end{array}$ & $\begin{array}{l}\text { ND } \\
0.4(H)\end{array}$ & $\begin{array}{l}\text { ND } \\
2.5(\mathrm{R})\end{array}$ \\
\hline
\end{tabular}

${ }^{a}$ The letters within parentheses indicate sensitivity to benzylpenicillin as follows: $\mathrm{H}$, highly sensitive (ID $_{50}$, $\approx 0.01$ to $0.06 \mu \mathrm{M}) ; \mathrm{M}$, moderately sensitive $\left(\mathrm{ID}_{50}, \approx 2\right.$ to $\left.6 \mu \mathrm{M}\right) ; \mathrm{R}$, resistant.

${ }^{b}$ As determined in reaction mixtures containing $1 \%$ Triton $\mathrm{X}-100$. The presence of the detergent caused an approximately 10 -fold increase in enzyme activity as compared with reaction mixtures containing the same cell envelopes without Triton X-100. The addition of Triton X-100 had little or no effect in all other cases.

c The inhibitory effect exerted by increasing concentrations of benzylpenicillin was biphasic, showing that, under the assay conditions used, the moderately penicillin-sensitive peptidase activity represented 10 to $20 \%$ of the total activity.

${ }^{d}$ ND, Not detected.

penicillin concentration. The removal of Genapol X-100 caused irreversible enzyme denaturation.

(iii) Penicillin-insensitive LD-carboxypeptidase. Filtration of water-soluble LD-carboxypeptidase on Ultrogel AcA4-4 indicated a molecular weight of 32,000. The enzyme activity increased as the $\mathrm{pH}$ of the reaction mixture increased from pH 7.5 (Tris-hydrochloride buffer) to 11 (Glycine- $\mathrm{NaOH}$ buffer). At $\mathrm{pH} 8.9$, variations of the molarity of the Tris-hydrochloride buffer from 0.02 to 0.22 were without any effect, and the $K_{m}$ value for the hydrolysis of UDP- $N$-acetylmuramyl-tetrapeptide was $0.4 \mathrm{mM}$. The free tetrapeptide and the amidated tetrapeptide had equivalent substrate activities.

\section{DISCUSSION}

The present investigation confirms the results previously obtained by Martin et al. (13) on the L-form strains of $\boldsymbol{P}$. mirabilis LVI and LD52 (8) and expands them by showing that the stable L-

TABLE 5. Antibiotic concentrations required to inhibit by $50 \%$ the purified DD-carboxypeptidasetranspeptidase $\mathrm{PBP}^{a}$

\begin{tabular}{|c|c|}
\hline Antibiotic & $\begin{array}{l}\mathrm{ID}_{s 0} \\
\text { value } \\
(\mu \mathrm{M})\end{array}$ \\
\hline $\begin{array}{l}\text { Benzylpenicillin } \ldots \ldots \ldots \ldots \\
\text { Ampicillin } \ldots \ldots \ldots \ldots \ldots \\
\text { Carbenicillin } \ldots \ldots \ldots \ldots \ldots \\
\text { Methicillin } \ldots \ldots \ldots \ldots \ldots \\
\text { Cephalothin } \ldots \ldots \ldots \ldots \ldots \ldots \\
\text { Mecillinam } . \ldots \ldots \ldots \ldots \ldots\end{array}$ & $\begin{array}{l}0.01 \\
0.006 \\
0.08 \\
1 \\
1 \\
2\end{array}$ \\
\hline
\end{tabular}

${ }^{a}$ The enzyme used had a specific activity of $4 \mathrm{U} / \mathrm{mg}$ of protein (carboxypeptidase assay). form derived from $P$. vulgaris P18 has kept the ability of the parental strain to synthesize all of the PBPs and the DD- and LD-peptidases known to be involved in peptidoglycan cross-linking and its further maturation during the bacterial life cycle. However, both the DD-carboxypeptidase-transpeptidase PBP4, which in the parental strain is loosely bound to the outer surface of the plasma membrane, and the LD-carboxypeptidase, which is located in the periplasmic region, are secreted in the culture medium during growth by the protoplast-like, stable L-forms. Mutants of $E$. coli lacking PBP4 (15) grow normally under a wide range of laboratory condi-

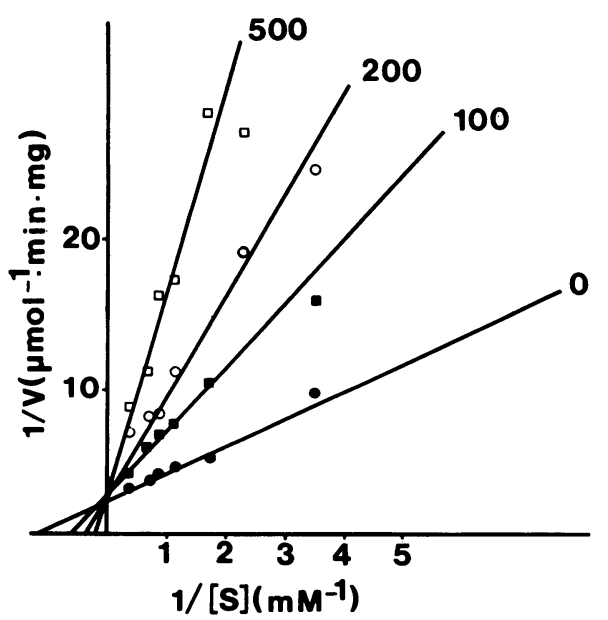

FIG. 2. Inhibition of the DD-carboxypeptidase activity of the isolated PBP4 by increasing concentrations of carbenicillin $(0,100,200$, and $500 \mathrm{nM})$. Lineweaver-Burk plot. 
tions, strongly suggesting that this PBP is dispensable. On this basis, a lack of integration of PBP4 within the plasma membrane is probably not at least the main defect for the hereditary and permanent inability of the stable L-forms to synthesize wall peptidoglycan. This inability may be due to defects in the early stages of peptidoglycan synthesis or, more likely, to defects in the subsequent lipid cycle possibly caused by the physical and chemical changes in the plasma membrane which permitted transition of Proteus mirabilis to life in the form of an envelopeless, osmotically stable L-form (6).

\section{ACKNOWLEDGMENTS}

The work has been supported in part by grants from an Action concertee with the Belgian Government (convention 79/84-I1), the Fonds de la Recherche Scientifique Médicale, Brussels, Belgium (contract 3.4501.79), and the National Institutes of Health (Public Health Service grant 5 RO1 AI13364-05).

\section{LITERATURE CITED}

1. Fleck, J. 1963. Etude de la croissance en milieu liquide d'une souche de Proteus et de sa forme L. C. R. Soc. Biol. 157:183-185.

2. Frère, J. M., M. Leyh-Bouille, J. M. Ghuysen, M. Nieto, and H. R. Perkins. 1976. Exocellular DD-carboxypeptidases-transpeptidases from Streptomyces. Methods Enzymol. 45:610-636.

3. Frère, J. M., M. Leyh-Bouille, J. M. Ghuysen, and H. R. Perkins. 1974. Interaction between $\beta$-lactam antibiotics and exocellular DD-carboxypeptidase-transpeptidase of Streptomyces R61. Eur. J. Biochem. 50:203-214.

4. Georgopapadakou, N. H., and F. M. Liu. 1980. Penicillinbinding proteins in bacteria. Antimicrob. Agents Chemother. 18:148-157.

5. Ghuysen, J. M. 1980. Antibiotics and peptidoglycan metabolism, p. 9-117. In P. G. Sammes (ed.), Topics in antibiotic chemistry, vol. 5. Ellis Horwood, Chichester.

6. Gmeiner, J., and H. H. Martin. 1976. Phospholipid and lipopolysaccharide in Proteus mirabilis and its stable protoplast L-form. Difference in content and fatty acid composition. Eur. J. Biochem. 67:487-494.

7. Izaki, K., and J. L. Strominger. 1968. Biosynthesis of peptidoglycan of bacterial cell walls. XIV. Purification and properties of two D-alanine carboxypeptidases from Escherichia coli. J. Biol. Chem. 243:3193-3201.

8. Kandler, O., and G. Kandler. 1956. Trennung and Charakterisierung verschiedener L-Phasen-Typen von Proteus mirabilis. Z. Naturforsch. 11:252-259.

9. Kohn, A. 1960. Lysis of frozen and thawed cells of
Escherichia coli by lysozyme and their conversion into spheroplasts. J. Bacteriol. 79:697-706.

10. Lowry, O. H., N. J. Rosenbrough, A. L. Farr, and R. J. Randall. 1951. Protein measurement with the Folin phenol reagent. J. Biol. Chem. 193:265-275.

11. Martin, H. H., C. Maskos, and R. Burger. 1975. D-alanylD-alanine carboxypeptidase in the bacterial form and Lforms of Proteus mirabilis. Eur. J. Biochem. 55:465-473.

12. Martin, H. H., W. Schilf, and C. Maskos. 1976. Purification of the membrane-bound DD-carboxypeptidase of the unstable spheroplast L-form of Proteus mirabilis by affinity chromatography. Eur. J. Biochem. 71:585-593.

13. Martin, H. H., W. Schilf, and H. G. Schieffer. 1980. Differentiation of mycoplasmatales from bacterial protoplast L-forms by assay for penicillin-binding proteins. Arch. Microbiol. 27:297-299.

14. Martin, H. H., M. Tonn-Ehlers, and W. Schilf. 1980. Cooperation of benzylpenicillin and cefoxitin in bacterial growth inhibition. Phil. Trans. R. Soc. London B 289:365367.

15. Matsuhashi, M., Y. Takagaki, I. N. Maruyama, S. Tamaki, Y. Nishimura, H. Suzuki, U. Ogino, and Y. Hirota. 1977. Mutants of Escherichia coli lacking in highly penicillin-sensitive D-alanine carboxypeptidase activity. Proc. Natl. Acad. Sci. U.S.A. 74:2976-2979.

16. Medill-Brown, M., W. G. Hutchinson, and E. Cocklin. 1960. The L-forms of Proteus mirabilis. Ann. N.Y. Acad. Sci. 79:372-379.

17. Minck, R., A. Kirn, and M. Galleron. 1957. Recherches sur la transformation $L$ en milieux synthétiques d'une souche de Proteus. Ann. Inst. Pasteur 92:138-141.

18. Nguyen-Disteche, M., J. M. Ghuysen, J. J. Pollock, P. E. Reynolds, H. R. Perkins, J. Coyette, and M. R. J. Salton. 1974. Enzymes involved in wall peptide crosslinking in Escherichia coli K12 strain 44. Eur. J. Biochem. 41:447455.

19. Nossal, N. G., and L. A. Heppel. 1966. The release of enzymes by osmotic shock from Escherichia coli in exponential phase. J. Biol. Chem. 241:3055-3062.

20. Ohya, S., M. Yamazaki, S. Sugawara, and M. Matsuhashi. 1979. Penicillin-binding proteins in Proteus species. J. Bacteriol. 137:474-479.

21. Ribi, E., T. Perrine, R. List, W. Brown, and G. Goode. 1959. Use of pressure cell to prepare cell walls from Mycobacteria. Proc. Soc. Exp. Biol. Med. 100:647-649.

22. Schilf, W., and H. H. Martin. 1980. Purification of two DD-carboxypeptidases-transpeptidases with different penicillin sensitivities from Proteus mirabilis. Eur. J. Biochem. 105:361-370.

23. Shepherd, S. T., H. A. Chase, and P. E. Reynolds. 1977. The separation and properties of two penicillin-binding proteins from Salmonella typhimurium. Eur. J. Biochem. 78:521-523.

24. Spratt, B. G. 1977. Properties of the penicillin-binding proteins of Escherichia coli K12. Eur. J. Biochem. 72:341-352.

25. Tulasne, R. 1949. Existence of L-forms in common bacteria and their possible importance. Nature (London) 164:876-877. 